\title{
Efficiency of the removal of microcystin-LR by UV-radiation and hydrogen peroxide
}

\author{
Eficiencia en la remoción de Microcistina-LR empleando radiación ultravioleta y peróxido de \\ hidrógeno
}

\author{
Jinna Marcela Loaiza-González (D) ${ }^{1}$, Melba Cristina León-Salazar (D) 1, Ainhoa Rubio-Clemente (D) 1, 2*, Diana C. \\ Rodríguez (iD) 1 , Gustavo A. Peñuela-Mesa (D) 1 \\ ${ }^{1}$ Grupo de Diagnóstico y Control de la Contaminación (GDCON), Universidad de Antioquia. Cr. 53 \# 61-30 Laboratorio 232, C. P. 050010. \\ Medellín, Colombia. \\ ${ }^{2}$ Facultad de Ingeniería, Tecnológico de Antioquia-Institución Universitaria TdeA. Cl. 78b \# 72A-220. C. P. 050034. Medellín, Colombia.
}

\section{CITE THIS ARTICLE AS:}

J. M. Loaiza, M. C. León, A. Rubio, D. C. Rodríguez and G. A. Peñuela. "Efficiency of the removal of microcystin-LR by UV-radiation and hydrogen peroxide", Revista Facultad de Ingeniería Universidad de Antioquia, no. 95, pp. 9-19, Apr-Jun 2020. [Online]. Available: https : //www.doi.org/10.17533/ udea.redin. 20190732

\section{ARTICLE INFO:}

Received: October 22, 2018

Accepted: July 12, 2019

Available online: July 12, 2019

\section{KEYWORDS:}

Water pollution; toxins; water treatment; advanced oxidation processes

Contaminación del agua; toxinas; tratamiento del agua; procesos de oxidación avanzada
ABSTRACT: Due to the harmful effects associated with the presence of microcystin-LR (MC-LR) cyanotoxin, photo-degradation assays were performed in natural and distilled water using the combined action of ultraviolet (UV) radiation and hydrogen peroxide $\left(\mathrm{H}_{2} \mathrm{O}_{2}\right)$. The effect of $\mathrm{H}_{2} \mathrm{O}_{2}$ content and UV irradiance was evaluated and optimized using a multilevel factorial design in distilled water spiked with $20 \mu \mathrm{g} \mathrm{L}^{-1} \mathrm{MC}-\mathrm{LR}$. The coupled $\mathrm{UV} / \mathrm{H}_{2} \mathrm{O}_{2}$ system under optimal operating conditions $10.63 \mathrm{~mW} \mathrm{~cm}{ }^{-2}$ irradiance and $30 \mathrm{mg} \mathrm{L}^{-1} \mathrm{H}_{2} \mathrm{O}_{2}$ ) was more effective than the individual action of UV irradiance or $\mathrm{H}_{2} \mathrm{O}_{2}$ content for 30 min of treatment time, since a reduction of $97.78 \%$ of MC-LR was achieved. After optimizing the operating conditions, they were applied for natural water, obtaining MC-LR removals similar to those achieved with distilled water 199.59 and $99.73 \%$, respectively), reaching a final MC-LR concentration in both matrices well below the maximum recommended limit established by WHO for MC-LR in drinking water, fixed at $1 \mu \mathrm{g} \mathrm{L}^{-1}$. $15 \mathrm{mg} \mathrm{L}^{-1}$ of $\mathrm{H}_{2} \mathrm{O}_{2}$ were also tested, and although $98.08 \%$ of MC-LR elimination was found for a reaction time of $60 \mathrm{~min}$, WHO advisable limit was not surpassed. The $\mathrm{UV} / \mathrm{H}_{2} \mathrm{O}_{2}$ process could be considered as an alternative to the conventional processes water facilities are operating with to tackle the problem of fresh water pollution with cyanotoxins, providing the accomplishment of the whole set of water quality standards included in the legislation.

RESUMEN: Debido a los efectos adversos asociados con la presencia de la cianotoxina microcistina-LR (MC-LR), se realizaron ensayos de fotodegradación en agua natural y destilada utilizando la acción combinada de la radiación ultravioleta (UV) y el peróxido de hidrógeno $\left(\mathrm{H}_{2} \mathrm{O}_{2}\right)$. El efecto del contenido de $\mathrm{H}_{2} \mathrm{O}_{2}$ y la irradiación UV se evaluó y optimizó utilizando un diseño factorial multinivel en agua destilada enriquecida con 20 $\mu \mathrm{g}$ de $\mathrm{L}^{-1} \mathrm{MC}$-LR. El sistema acoplado $\mathrm{UV} / \mathrm{H}_{2} \mathrm{O}_{2}$ en condiciones óptimas $10.63 \mathrm{~mW} \mathrm{~cm}{ }^{-2}$

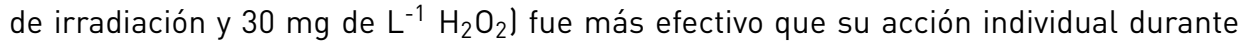
30 min de tratamiento, ya que se logró una reducción del $97.78 \%$ de MC-LR. Después de optimizar las condiciones de operación, se aplicaron para agua natural, obteniendo remociones de MC-LR similares a las obtenidas con agua destilada 199.59 y $99.73 \%$, respectivamente), alcanzando una concentración final de MC-LR en ambas matrices muy por debajo del límite máximo recomendado por la OMS para MC-LR en agua potable, fijado en $1 \mu \mathrm{g} \mathrm{L}^{-1}$. También se probó $15 \mathrm{mg} \mathrm{L}^{-1}$ de $\mathrm{H}_{2} \mathrm{O}_{2}$, y aunque se encontró un $98.08 \%$ de eliminación de MC-LR durante $60 \mathrm{~min}$, el límite aconsejable de la OMS no se superó. El proceso UV/ $\mathrm{H}_{2} \mathrm{O}_{2}$ podría considerarse una alternativa a los procesos convencionales de potabilización para abordar el problema de la contaminación del agua dulce con cianotoxinas, proporcionando el cumplimiento de los estándares de calidad del agua legislados.

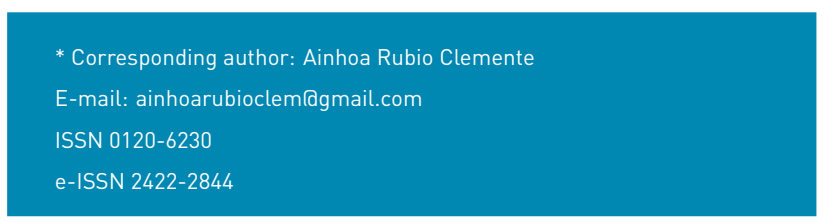




\section{Introduction}

Cyanobacteria are unicellular photosynthetic organisms present in a wide range of aquatic ecosystems [1]. Cyanobacteria are very common in lentic ecosystems like reservoirs, especially in tropical zones where their growth is promoted by high temperatures and nutrient abundance. These conditions lead to eutrophication of aqueous systems, which in turn induces an unmeasured growth of phytoplankton; a phenomenon known as "bloom" [1]. In addition to other problems caused by eutrophication, this rapid and exponential population growth can lead to the production of so-called cyanobacterial toxins, also known as toxic secondary metabolites, produced by certain cyanobacteria, which threaten the health of humans and other living species. These detrimental effects are more significant for the animals that inhabit these ecosystems or humans that use the affected water for irrigation, recreation or water supply without efficient removal treatments [2].

Cyanobacteria include a wide variety of genera and species. Some of these produce very specific toxins, while others generate a spectrum of toxins with varied intoxication mechanisms, acting at the level of cells (cytotoxicity), organs like the liver (hepatotoxicity), or systems, like the nervous system (neurotoxicity) [2]. Moreover, these cyanotoxins have bioaccumulation potential [3].

Hepatotoxins are likely to be the most common cyanotoxins produced by cyanobacteria. They conform a structurally diverse group, including over 90 different microcystins (MCs) [4]. Microcystins and nodularins are the most frequently found cyanobacterial toxins in brackish and fresh water worldwide [2].

MCs are produced by many cyanobacterial genera, including Microcystis sp., Oscillatoria sp., Nostoc sp., Anabaena sp. and Anabaenopsis sp. The synthesis of these toxins is a very complex process, influenced by environmental conditions, and varying depending on each strain present in the water $[2,5]$. The toxicity level of a mixture of these cyanotoxins will vary according to the kind of toxins present in the water. In fact, MC-LR is the general reference for $\operatorname{MCs}[5,6]$. Due to several intoxication reports, the World Health Organization (WHO) has suggested $1 \mu \mathrm{g} \mathrm{L} \mathrm{L}^{-1}$ as the maximum allowable concentration for MC-LR in drinking water.

MCs are water soluble molecules with a cyclic peptide structure composed of seven amino acids, and a lateral "Adda" chain with a double conjugated bond, as observed in Table 1. Its toxicity is thought to be explained by this. From a structural point of view, these molecules are characterized by their chemical stability. Indeed, MCs are resistant to boiling, chemical hydrolysis and oxidation at a $\mathrm{pH}$ close to neutrality. In natural water and under dark conditions, MCs can remain stable for months or even years $[4,6]$.

Many conventional treatment methods for drinking water production, such as coagulation, flocculation, sedimentation and filtration, allow the removal of cyanobacterial cells, thus preventing cell lysis and toxin release. However, under common operational conditions these traditional water treatment processes cannot guarantee the effective elimination of extracellular cyanobacterial toxins that were already present before the treatment began [5-7].

In order to tackle the problem of cyanotoxin pollution in water, previous studies suggest the application of advanced oxidation processes (AOPs). Among these, the combination of UV-radiation with an oxidizing agent such as hydrogen peroxide $\left(\mathrm{H}_{2} \mathrm{O}_{2}\right)$ stands out as a viable solution for the remediation of water contaminated with cyanotoxins, by allowing the formation of the free hydroxyl radical $\left(\mathrm{HO}^{\circ}\right)$, as a powerful oxidizing agent $\left(E^{0}=2.8 \mathrm{~V}\right)$ [8-12].

Keeping in view the facts mentioned above, MC-LR cyanotoxin removal efficiency using a UV/ $\mathrm{H}_{2} \mathrm{O}_{2}$ system both in natural water and in distilled water was evaluated in the present work. For this purpose, different combinations of $\mathrm{H}_{2} \mathrm{O}_{2}$ initial concentration and UV irradiance were assessed using a multilevel factorial design of experiments with the aim of finding the optimal working conditions of the oxidation system to control the problem of MC-LR natural water pollution and, subsequently, to produce safe drinking water in compliance with all legally stipulated parameters for public consumption.

\section{Materials and methods}

\subsection{Reagents}

A MC-LR standard solution bioreagent grade (from Microcystis aeruginosal $\mathrm{C}_{49} \mathrm{H}_{74} \mathrm{~N}_{10} \mathrm{O}_{12}$ ( $>95.5 \%$ purity), HPLC grade, was obtained from Cyano Biotech $\mathrm{GmbH}$ (Berlin, Germany). $10 \mathrm{~mL} 500 \mu \mathrm{g} \mathrm{L}^{-1}$ was prepared using methanol as solvent. Hydrogen peroxide, $\mathrm{H}_{2} \mathrm{O}_{2} 30 \%(\mathrm{w} / \mathrm{w})$, was obtained from J.T. Baker (Ecatepec, Mexico State, Mexico) and anhydrous sodium sulfite $\left(\mathrm{Na}_{2} \mathrm{SO}_{3} 98 \%\right.$ pure), from Carlo Erba Reagents (Sabadell, Spain). Methanol solvent used was LC/MS grade and supplied by J.T Baker. Deionized water, used for MC-LR determination, was obtained from a Millipore water purification system (Bedford, MA, USA). 
Table 1 General characteristics of microcystin-LR (MC-LR)

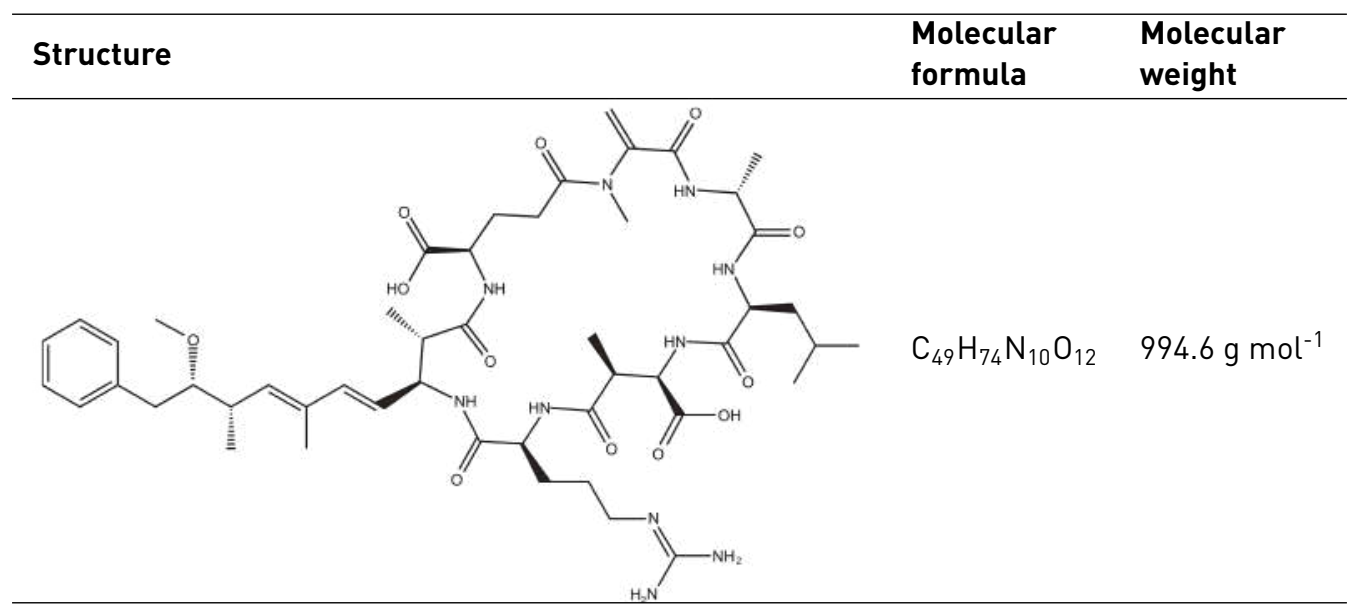

\subsection{MC-LR determinations}

MC-LR concentration was monitored over time using an ultra-high-performance liquid chromatography-tandem mass spectrometer UHPLC-MS/MS (Waters Acquity H-Class), (Xevo TQD). The toxin was previously extracted and concentrated using solid phase extraction (SPE) procedure.

Each sample was filtrated through mixed cellulose ester filters with $0.45 \mu \mathrm{m}$ pore size. Subsequently, MC-LR was extracted following the SPE procedure for concentrating and cleaning the toxins with a $200 \mathrm{mg} / 6 \mathrm{~mL}$ Hidrophilic Lipohilic Balance cartridge. The cartridge was initially purged with $10 \mathrm{~mL}$ of methanol, followed by $10 \mathrm{~mL}$ of deionized water. After that, $100 \mathrm{~mL}$ from each previously filtrated water sample was vacuum-filtrated through the cartridge at a $3 \mathrm{~mL} \mathrm{~min}^{-1}$ flux. $5 \mathrm{~mL}$ of deionized water was then added and the cartridge were left to dry for $30 \mathrm{~min}$. Afterwards, the analytes were eluted with 10 $\mathrm{mL}$ of $90 / 10$ methanol/deionized water. Finally, each sample was dried with nitrogen gas for around $3 \mathrm{~h}$ and resuspended in $1 \mathrm{~mL}$ of 90/10 methanol/deionized water. The sample was then filtrated, this time through a 0.22 $\mu \mathrm{m}$ nylon membrane filter, and deposited in a certificated LC-MS/MS vial. In this way, a 100 concentration factor was obtained. In addition to the sample analysis, a replicate, an enriched sample, a $20 \mu \mathrm{g} \mathrm{L}^{-1}$ control and a blank were used as analytical controls and were analyzed according to the quality management system of GDCON research group.

With respect to the chromatographic conditions, 20 $\mu \mathrm{L}$ of each prepared sample was injected into the LC-MS/MS system. For separation purposes, a $2.1 \mathrm{~mm}$ X $50 \mathrm{~mm}$ ACQUITY UPLC BEH Shield RP18 column of 1.7 $\mu \mathrm{m}$ particle size was used. UHPLC conditions were as follows: $30{ }^{\circ} \mathrm{C}$ column temperature, $0.25 \mathrm{~mL} \mathrm{~min}^{-1}$ flux and 10.5 min running time. Deionized water was used in the mobile phase with $20 \mathrm{mM}$ ammonium formate along with an organic solution consisting of LC-MS/MS grade methanol with $20 \mathrm{mM}$ ammonium formate. Meanwhile, operating conditions for the mass spectrometer were 150 and $350{ }^{\circ} \mathrm{C}$ as the source and desolvation temperatures, respectively; 650 and $50 \mathrm{~L} \mathrm{~h}^{-1}$ as the desolvation and cone gas flux; ESI $(+)$ ionization mode and $3.7 \mathrm{kV}$ capillarity voltage.

For the quantification of the $M C-L R$, a calibration curve was constructed from $5-80 \mu \mathrm{g} \mathrm{L}^{-1}(5,10,30,50,60$ and $80 \mu \mathrm{g} \mathrm{L}^{-1}$ ). The quantification limit (LoQ) was $5.0 \mu \mathrm{g}$ $\mathrm{L}^{-1}$. The lowest value detected in the samples was 0.05 $\mu \mathrm{g} \mathrm{L}^{-1}$ (LoD). Samples were quantified using the linear regression obtained from the calibration curve.

\subsection{Photochemical experiments and experimental design}

For the MC-LR removal experiments, natural water from a wetland located in "El Porvenir", in Rionegro (Antioquia, Colombia), and distilled water were used. Their physicochemical characteristics are listed in Table 2.

A $2 \mathrm{~L}$ effective capacity jacketed photochemical reactor with 4 germicidal low pressure lamps emitting mainly at $254 \mathrm{~nm}$ with $0.63 \mathrm{~mW} \mathrm{~cm}^{-2}$ irradiance, verified through a UVX radiometer (Upland, CA, USA), was used for the UV-radiation simulation. $\mathrm{H}_{2} \mathrm{O}_{2}$ was evaluated at 15 and $30 \mathrm{mg} \mathrm{L}^{-1}$ concentration levels. The reaction solution temperature was kept stable with the external refrigeration jacket. Homogeneity was kept through continuous agitation at $260 \mathrm{rpm}$. Before starting the experiments, the UV lamps were warmed up for 30 min to ensure stable emission. Samples were spiked with $20 \mu \mathrm{g}$ $\mathrm{L}^{-1} \mathrm{MC}$-LR. Aliquots of $100 \mathrm{~mL}$ were withdrawn at different time intervals during the oxidation treatment. In order to 
Table 2 Physicochemical water quality parameters

\begin{tabular}{|c|c|c|}
\hline Parameters & Natural water & Distilled water \\
\hline $\mathrm{pH}$ & 5.8 & 6.3 \\
\hline Turbidity (NTU) & 117 & 0.07 \\
\hline Ammoniacal nitrogen $\left(\mathrm{mg} \mathrm{N}-\mathrm{NH}_{4^{+}} \mathrm{L}^{-1}\right)$ & 8.724 & LoQ \\
\hline Total nitrogen Kjeldahl (mg NTK L L ${ }^{-1}$ ) & 24.456 & LoQ \\
\hline Nitrates (mg NO${ }_{3}^{-} \mathrm{L}^{-1}$ ) & 0.711 & LoQ \\
\hline Nitrites (mg NO${ }_{2} \mathrm{~L}^{-1}$ ) & LoQ & LoQ \\
\hline Sulphates $\left(\mathrm{mg} \mathrm{SO}_{4}{ }^{2-} \mathrm{L}^{-1}\right)$ & 5.237 & LoQ \\
\hline Chloride (mg Cl- $\mathrm{L}^{-1}$ ) & 2.708 & LoQ \\
\hline Phosphate (mg PO $\left.4{ }^{3-} \mathrm{L}^{-1}\right)$ & 4.325 & LoQ \\
\hline Dissolved iron (mg Fe L'-1) & 0.125 & LoQ \\
\hline Total hardness $\left(\mathrm{mg} \mathrm{CaCO}_{3} \mathrm{~L}^{-1}\right)$ & 75.51 & LoQ \\
\hline Total alkalinity $\left(\mathrm{mg} \mathrm{CaCO}_{3} \mathrm{~L}^{-1}\right)$ & 44.460 & LoQ \\
\hline $\mathrm{TOC}\left(\mathrm{mg} \mathrm{C} \mathrm{L^{-1 } )}\right.$ & 90.33 & LoQ \\
\hline Absorbance $254 \mathrm{~nm}$ & 0.680 & 0 \\
\hline
\end{tabular}

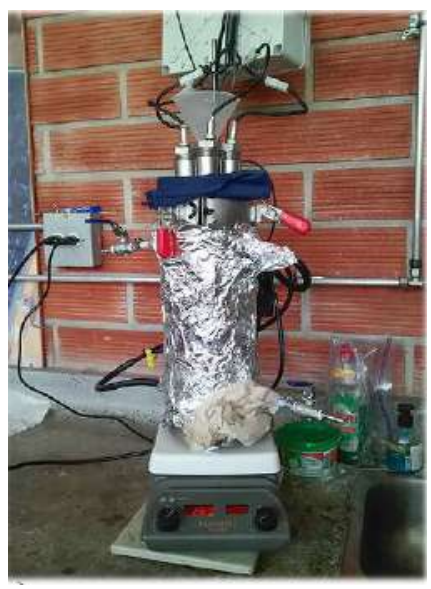

(a) Photochemical reactor

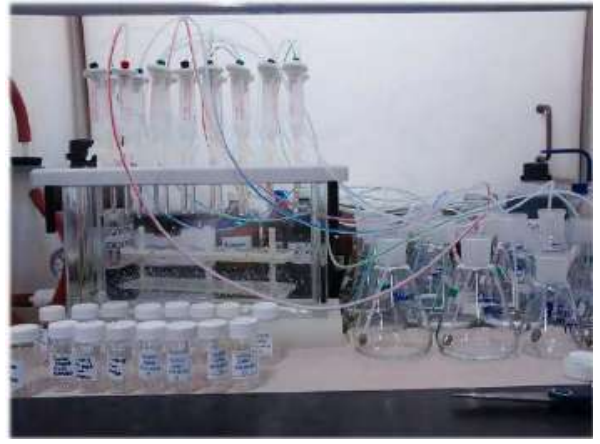

(b) Solid phase extraction (SPE) procedure

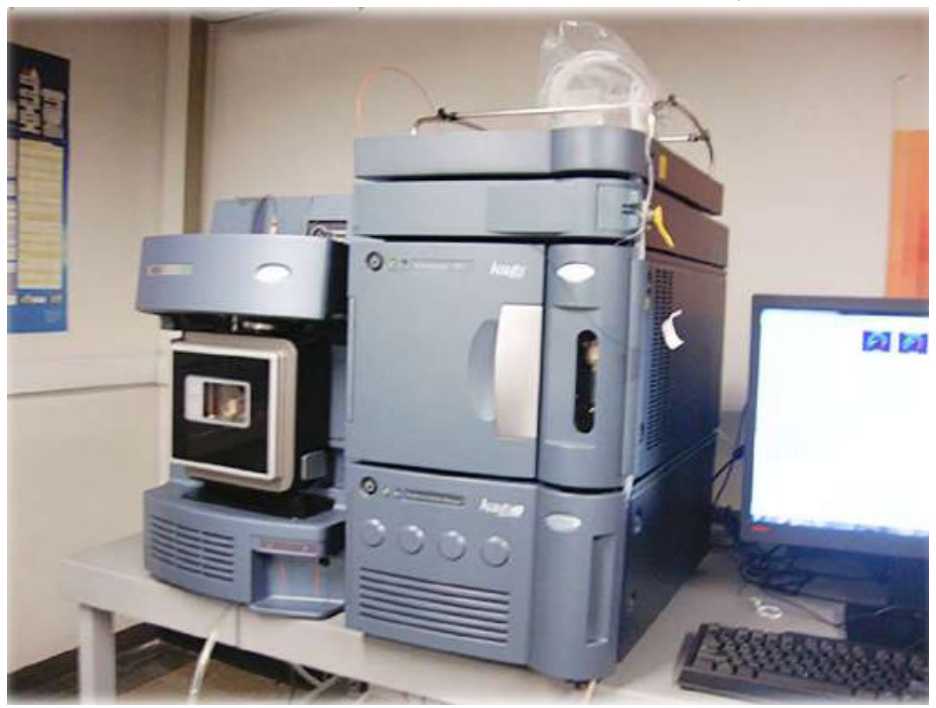

(c) Ultra-high-performance liquid chromatography-tandem mass spectrometer UHPLC-MS/MS (Waters Acquity H-Class), (Xevo TQD)

Figure 1 Experimental setup 
stop the action of $\mathrm{H}_{2} \mathrm{O}_{2}, \mathrm{Na}_{2} \mathrm{SO}_{3}$ was added immediately. Residual MC-LR in the reaction solution was analyzed through the SPE-UHPLC-MS/MS method previously described. In Figure 1, the experimental setup, composed of the photochemical reactor, the solid phase extraction (SPE) procedure and the ultra-high-performance liquid chromatography-tandem mass spectrometer, is illustrated.

The effects of the oxidizing agent and the UV-radiation, in terms of UV irradiance, were evaluated using a multilevel factorial design of experiments (DOE), resulting in 6 runs, which were executed randomly. Every run was carried out in triplicate and average values were reported. Analysis of variance (ANOVA) test was conducted and a second-order regression model, described by Equation 1, was built.

$$
\begin{array}{r}
y=\beta_{0}+\sum_{i=1}^{2}\left(\beta_{i} x_{i}\right)+\sum_{i=1}^{2} \beta_{i i} x_{i i}^{2}+ \\
\sum_{i=1}^{2} \sum_{j=1, i<j}^{2} \beta_{i j} x_{i} x_{j}+\varepsilon
\end{array}
$$

where $y$ denotes the removal percentage of MC-LR for 30 min of treatment; $\beta_{o}$ is the intercept; $\beta_{i}, \beta_{i}, \beta_{i i}$ and $\beta_{i j}$ refer to the linear, quadratic and interaction regression coefficients, respectively; $x_{i}$ represents the levels of the independent variables; and $\varepsilon$ is the experimental error.

By optimizing the response variable, the optimal operating conditions that allow obtaining the highest removal of MC-LR for each factor within the experimental domain were found in distilled water for $30 \mathrm{~min}$ of treatment. Under the calculated optimal working conditions, the MC-LR elimination efficiency of the oxidation system for a reaction time of 60 min was investigated and compared to that found for the removal of MC-LR in fresh natural water.

The statistical treatment of the experimental data was performed using Statgraphics Centurion XVII (Statpoint, Warrenton, USA).

\section{Result and discussion}

Promising results were obtained for the $\mathrm{UV} / \mathrm{H}_{2} \mathrm{O}_{2}$ system, both in the distilled and natural water tested. Removal values higher than $99 \%$ were achieved.

\subsection{Optimization studies of the $\mathrm{UV} / \mathrm{H}_{2} \mathrm{O}_{2}$ system operating conditions}

For the implementation of the $\mathrm{UV} / \mathrm{H}_{2} \mathrm{O}_{2}$ system, a multilevel factorial DOE was performed. For this purpose, the UV irradiance and the $\mathrm{H}_{2} \mathrm{O}_{2}$ content were considered as main factors and were evaluated at 210 and $0.63 \mathrm{~mW}$ $\left.\mathrm{cm}^{-2}\right)$ and $3\left(0,15\right.$ and $\left.30 \mathrm{mg} \mathrm{L}^{-1}\right)$ levels, respectively. The response variable was the removal percentage of MC-LR at $30 \mathrm{~min}$ of treatment, in order to discern their optimal working conditions and to examine the effects of the two controllable variables selected for studying the efficiency of the system. In Table 3, the DOE matrix composed of 6 runs executed randomly, and the levels of the considered factors are listed. Additionally, the experimental and calculated removal percentages of MC-LR cyanotoxin are reported.

In order to build the second-order regression model that correlated the removal percentage of MC-LR with the UV/ $\mathrm{H}_{2} \mathrm{O}_{2}$ system factors, ANOVA test was performed (Table 4). It can be observed that the UV irradiance, the oxidizing agent and the interaction effect of both factors were significant from a statistical point of view at $95 \%$ of confidence interval due to the low p-values (lower than 0.05) and large F-ratio associated with. The quadratic term for $\mathrm{H}_{2} \mathrm{O}_{2}$ concentration resulted to be statistically non-significant; however, since its p-value was near 0.05 , it was included in the second-order polynomial regression model.

The second-order regression model resulting from the ANOVA test is described by Equation 2.

$$
\begin{aligned}
& \text { Cyanotoxin removal } \\
& =0.975+65.6349 \text { UV irradiance } \\
& +1.06333 \mathrm{H}_{2} \mathrm{O}_{2}+2.82011 \text { UV irradiance } * \mathrm{H}_{2} \mathrm{O} 2 \\
& -0.0327778 *\left(\mathrm{H}_{2} \mathrm{O}_{2}\right)^{2}
\end{aligned}
$$

The adequacy and significance of the developed regression model representing the removal of MC-LR cyanotoxin were studied. The model resulted to be statistically significant (regression p-value was 0.0125 at $5 \%$ of significance level), explaining the $99.99 \%$ and $99.96 \%$ of the variability in the MC-LR cyanotoxin elimination efficiency by the resulting determination coefficient and the adjusted determination coefficient $\left(\mathrm{R}^{2}\right.$ and $\mathrm{R}^{2}$ adj, respectively). Additionally, Shapiro-Wilk test $p$-value (0.18734) was higher than 0.05 , which indicated that the obtained experimental data were normally distributed. In addition, constant homoscedasticity and factor independency assumptions were also accomplished. Therefore, from those results, it can be concluded that the second-order regression model built can adequately and significantly predict the efficiency of the oxidation system studied for reducing the concentration of MC-LR in distilled water.

The magnitude and significance of the effects of the variables as single, quadratic and interaction effects are 
Table 3 Selected factors levels, experimental matrix and MC-LR removal percentages by the implementation of the UV/ $\mathrm{H}_{2} \mathrm{O}_{2}$ system

\begin{tabular}{|c|c|c|c|c|}
\hline & \multicolumn{2}{|c|}{ Factor } & \multicolumn{2}{|c|}{ Level } \\
\hline & \multicolumn{2}{|c|}{ UV irradiance $\left(\mathrm{mW} \mathrm{cm}^{-2}\right)$} & \multicolumn{2}{|c|}{0 and 0.63} \\
\hline & \multicolumn{2}{|c|}{$\mathrm{H}_{2} \mathrm{O}_{2}$ concentration (mg L ${ }^{-1}$ ) } & \multicolumn{2}{|c|}{0.15 and 30} \\
\hline & \multicolumn{2}{|c|}{ Factor } & \multicolumn{2}{|c|}{ Response } \\
\hline Run & $\begin{array}{l}\text { UV irradiance } \\
\left(\mathrm{mW} \mathrm{cm}^{-2}\right)\end{array}$ & $\begin{array}{l}\mathrm{H}_{2} \mathrm{O}_{2} \text { concentration } \\
\left(\mathrm{mg} \mathrm{L}^{-1}\right)\end{array}$ & $\begin{array}{l}\text { MC-LR experimental } \\
\text { removal }(\%)\end{array}$ & $\begin{array}{l}\text { MC-LR calculated } \\
\text { removal }(\%)\end{array}$ \\
\hline 1 & 0.0 & 0.0 & 1.2 & 0.9 \\
\hline 2 & 0.63 & 0.0 & 42.1 & 42.3 \\
\hline 3 & 0.0 & 15.0 & 9.1 & 9.6 \\
\hline 4 & 0.63 & 15.0 & 78.0 & 77.6 \\
\hline 5 & 0.0 & 30.0 & 3.6 & 3.4 \\
\hline 6 & 0.63 & 30.0 & 97.8 & 98.0 \\
\hline
\end{tabular}

Table 4 Analysis of variance (ANOVA) describing the removal of MC-LR cyanotoxins by the UV/ $\mathrm{H}_{2} \mathrm{O}_{2}$ system

\begin{tabular}{llllll}
\hline Source & Sum of Squares & Df & Mean Square & F-Ratio & P-Value \\
\hline A:UV irradiance & 6936.0 & 1 & 6936.0 & 11417.28 & 0.0060 \\
$\mathrm{~B}: \mathrm{H}_{2} \mathrm{O}_{2}$ & 843.902 & 1 & 843.902 & 1389.14 & 0.0171 \\
$\mathrm{AB}$ & 710.222 & 1 & 710.222 & 1169.09 & 0.0186 \\
$\mathrm{BB}$ & 72.5208 & 1 & 72.5208 & 119.38 & 0.0581 \\
Total error & 0.6075 & 1 & 0.6075 & & \\
Total (corr.) & 8563.25 & 5 & & & \\
\hline
\end{tabular}

shown in the Pareto chart (Figure 2). It can be observed that the UV irradiance and the $\mathrm{H}_{2} \mathrm{O}_{2}$ concentration developed a significant positive effect on the removal of MC-LR cyanotoxin in distilled water, as well as the interaction effect between the irradiance and the oxidizing agent. That positive impact of the UV irradiance and the $\mathrm{H}_{2} \mathrm{O}_{2}$ content on the oxidation system can be also observed from Figure 3, representing the effect of the main factors. This is indicative that the elimination of MC-LR in distilled water increased as the factors went from their low to their high levels.

The positive influence of the UV irradiance on the system can be explained from the important role developed by this factor in photon-based AOPs, such as the UV/ $\mathrm{H}_{2} \mathrm{O}_{2}$ system. In fact, irradiance resulted to be the most significant factor on the UV/ $\mathrm{H}_{2} \mathrm{O}_{2}$ system for the removal of MC-LR cyanotoxin within the experimental domain tested, since the amount of $\mathrm{HO}^{\circ}$ formed has been reported to be closely related to the amount of photons interacting the reaction solution and producing the homolysis of $\mathrm{H}_{2} \mathrm{O}_{2}$, as described by Equation 3, resulting in an improvement of the oxidation system efficiency.

$$
\mathrm{H}_{2} \mathrm{O}_{2}+h v \rightarrow 2 \mathrm{HO}^{\circ}
$$

In turn, the $\mathrm{H}_{2} \mathrm{O}_{2}$ concentration influenced positively the system under the experimental conditions tested here, as observed in Figure 2 and 3. Nonetheless, in Figure 3 a slight curvature can be evidenced near the high level of the oxidant content $\left(30 \mathrm{mg} \mathrm{L}^{-1}\right)$. It must be noted that, it has been generally stated that, at a low $\mathrm{H}_{2} \mathrm{O}_{2}$ level, the oxidation efficiency of the system is limited by the low $\mathrm{HO}^{\circ}$ production, which increases by increasing the $\mathrm{H}_{2} \mathrm{O}_{2}$ concentration (Equation 3), up to a certain point where an excessively high content of $\mathrm{H}_{2} \mathrm{O}_{2}$ inhibits the degradation rate, as it would be the case if the concentration of $\mathrm{H}_{2} \mathrm{O}_{2}$ was extended beyond $30 \mathrm{mg} \mathrm{L}^{-1}$, keeping constant the irradiation value of $0.63 \mathrm{~mW} \mathrm{~cm}^{-2}$. This phenomenon can be ascribed to the scavenging effect on $\mathrm{HO}^{\circ}$ developed by the oxidant $\left(\mathrm{H}_{2} \mathrm{O}_{2}\right)$, as represented in Equation 4, and the subsequent side effect reactions described by Equations from 5 to 8 [12]. In this scenario, any competitive reaction would reduce the MC-LR degradation rate [8]. According to this, the $\mathrm{H}_{2} \mathrm{O}_{2}$ threshold concentration was not reached in this study within the experimental domain. The $\mathrm{H}_{2} \mathrm{O}_{2}$ threshold concentration has been reported to vary for each particular case. For example, in general terms, the oxidant threshold level rises with the rise of the UV fluence [13]. Furthermore, the $\mathrm{H}_{2} \mathrm{O}_{2}$ threshold concentration varies according to the $\mathrm{pH}$ of the solution, the diverse components present in water and the cyanotoxin concentration [10]. Additionally, it is important to note that a lower initial MC-LR concentration has been evidenced to lead to a higher and more efficient removal [12]. This fact could be explained by the relative increase of the molar ratio $\mathrm{H}_{2} \mathrm{O}_{2} / \mathrm{MC}-\mathrm{LR}$ as the toxin concentration is decreased [10].

$$
\begin{gathered}
\mathrm{HO}^{o}+\mathrm{H}_{2} \mathrm{O}_{2} \rightarrow \mathrm{HO}_{2}{ }^{o}+\mathrm{H}_{2} \mathrm{O} \\
\mathrm{HO}_{2}{ }^{o}+\mathrm{H}_{2} \mathrm{O}_{2} \rightarrow \mathrm{HO}^{o}+\mathrm{H}_{2} \mathrm{O}+\mathrm{O}_{2}
\end{gathered}
$$




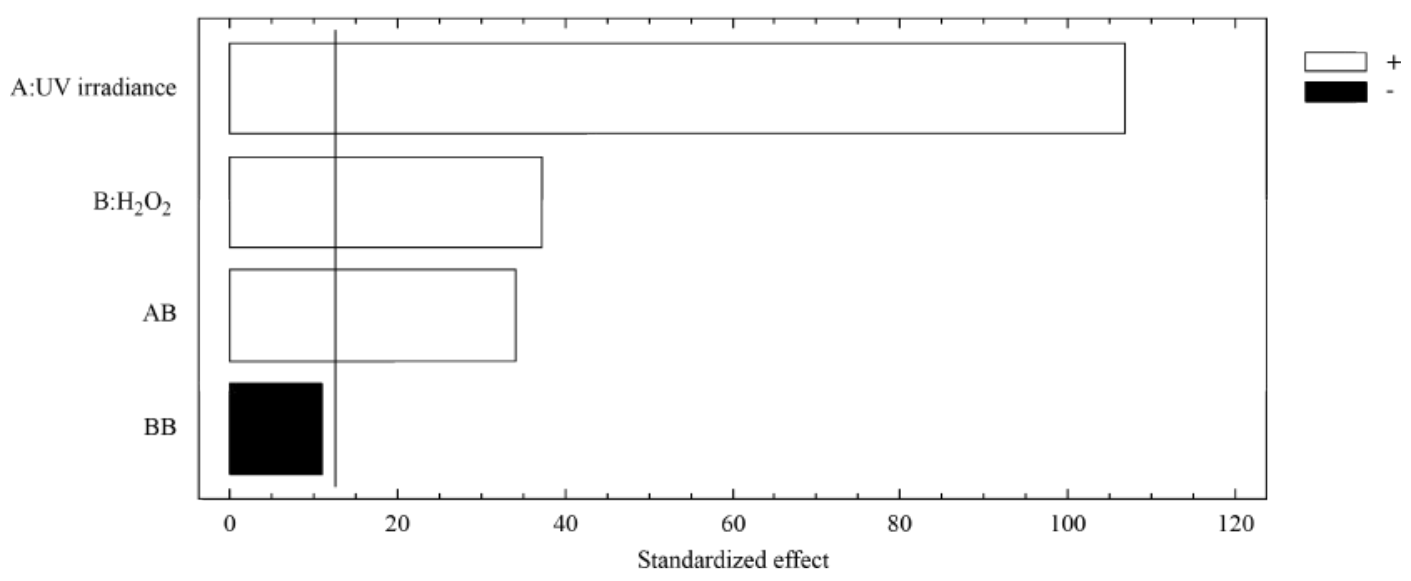

Figure 2 Pareto chart for the regression model describing the removal of MC-LR cyanotoxin in distilled water by the UV/ $\mathrm{H}_{2} \mathrm{O}_{2}$ system. $\left[\mathrm{H}_{2} \mathrm{O}_{2}\right]_{0}=0-30 \mathrm{mg} \mathrm{L}^{-1} ; \mathrm{UV}-\mathrm{C}$ irradiance $=0-0.63 \mathrm{~mW} \mathrm{~cm}^{-2} ;[\mathrm{MC}-\mathrm{LR}]_{0} \sim 20 \mu \mathrm{g} \mathrm{L}^{-1}$; treatment time $=30 \mathrm{~min}$

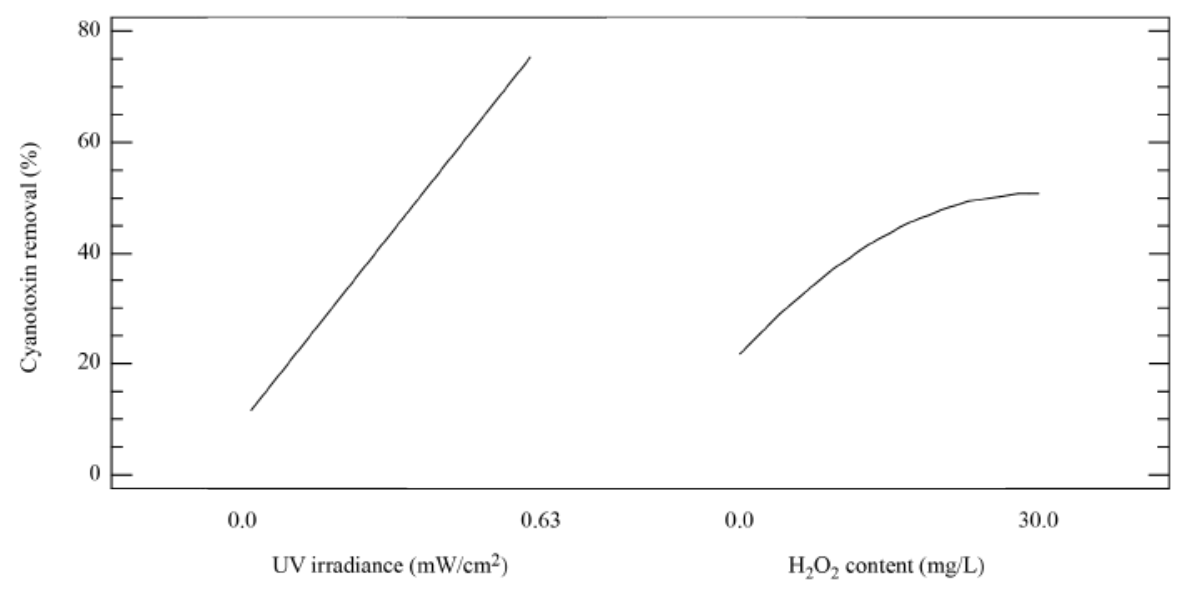

Figure 3 Main effect plot for the regression model describing the removal of MC-LR cyanotoxin in distilled water by the UV/ $\mathrm{H}_{2} \mathrm{O}_{2}$ system. $\left[\mathrm{H}_{2} \mathrm{O}_{2}\right]_{0}=0-30 \mathrm{mg} \mathrm{L}^{-1}$; UV-C irradiance $=0-0.63 \mathrm{~mW} \mathrm{~cm}^{-2}$; $[\mathrm{MC}-\mathrm{LR}]_{0} \sim 20 \mu \mathrm{g} \mathrm{L}^{-1}$; treatment time $=30 \mathrm{~min}$

$$
\begin{gathered}
2 \mathrm{HO}_{2}{ }^{\circ} \rightarrow \mathrm{H}_{2} \mathrm{O}_{2}+\mathrm{O}_{2} \\
\mathrm{HO}_{2}{ }^{o}+\mathrm{HO}^{\circ} \rightarrow \mathrm{H}_{2} \mathrm{O}_{2}+\mathrm{O}_{2} \\
\mathrm{HO}^{\circ}+\mathrm{HO}^{\circ} \rightarrow \mathrm{H}_{2} \mathrm{O}_{2}
\end{gathered}
$$

system within the experimental domain were exactly: 0.63 $\mathrm{mW} \mathrm{cm}{ }^{-2}$ and $30 \mathrm{mg} \mathrm{L}^{-1}$ for the UV irradiance and the $\mathrm{H}_{2} \mathrm{O}_{2}$ content, respectively.

The positive effects of the UV irradiance and the $\mathrm{H}_{2} \mathrm{O}_{2}$ concentration can also be observed from the sign " + " of the regression coefficients for these linear factors in the regression model represented by Equation 2. Additionally, these effects can be found in Figure 4, where the response surface and contour plot estimated by the regression model built are illustrated. From the figure, the optimal working region was observed to be located at $0.63 \mathrm{~mW}$ $\mathrm{cm}^{-2}$ and close to $30 \mathrm{mg} \mathrm{L}^{-1} \mathrm{H}_{2} \mathrm{O}_{2}$. In order to find exactly such as operating conditions, the response variable was optimized. The optimal conditions for achieving the highest elimination of MC-LR by the application of the UV/ $\mathrm{H}_{2} \mathrm{O}_{2}$

\subsection{Removal of MC-LR cyanotoxin by the $\mathrm{UV} / \mathrm{H}_{2} \mathrm{O}_{2}$ system operating under optimal conditions}

After evaluating the influence of each main factor and optimizing the oxidation system. Further experiments were conducted for assessing the MC-LR cyanotoxin removal capacity of the $U V / \mathrm{H}_{2} \mathrm{O}_{2}$ process under optimal working conditions by extending the reaction time at 60 min using distilled water. Results are represented in Figure 5. It can be concluded that by increasing $30 \mathrm{~min}$ the treatment time, the oxidation potential of the system was improved since higher MC-LR removal was observed, reaching a reduction of the MC-LR content of $99.73 \%$. 


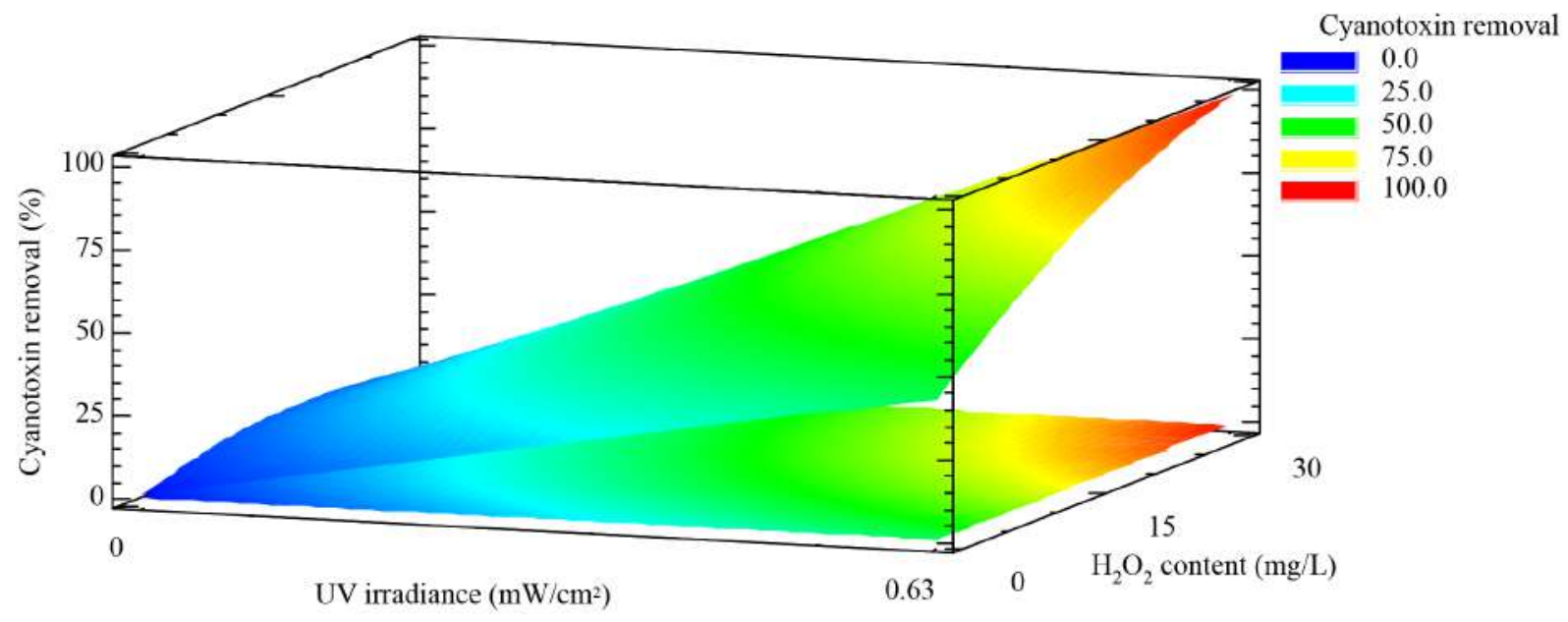

Figure 4 Response surface and contour plot for the regression model describing the removal of MC-LR cyanotoxin in distilled water by the UV/ $\mathrm{H}_{2} \mathrm{O}_{2}$ system. $\left[\mathrm{H}_{2} \mathrm{O}_{2}\right]_{0}=0-30 \mathrm{mg} \mathrm{L}^{-1} ; \mathrm{UV}-\mathrm{C}$ irradiance $=0-0.63 \mathrm{~mW} \mathrm{~cm}^{-2} ;[M C-\mathrm{LR}]_{0} \sim 20 \mu \mathrm{g} \mathrm{L}^{-1}$; treatment time $=30 \mathrm{~min}$

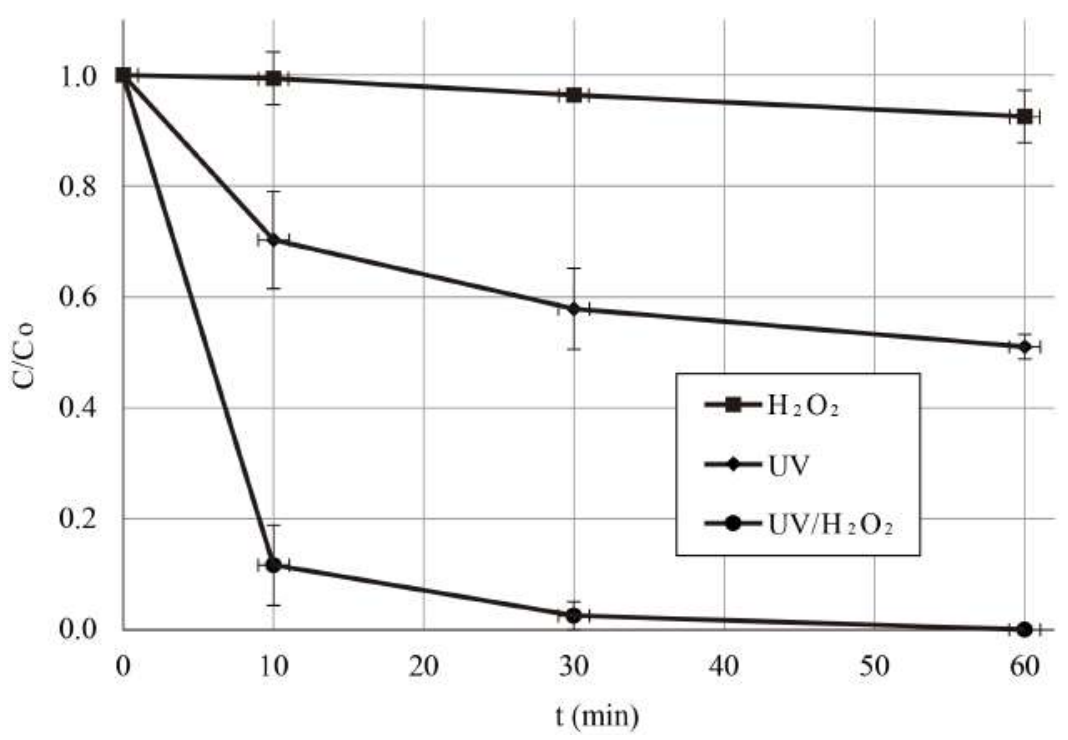

Figure 5 Removal profile of MC-LR cyanotoxin vs time during the $\mathrm{UV} / \mathrm{H}_{2} \mathrm{O}_{2}$ system application in distilled water under optimal operating conditions. $\left[\mathrm{H}_{2} \mathrm{O}_{2}\right]_{0}=30 \mathrm{mg} \mathrm{L}^{-1}$; UV-C irradiance $=0.63 \mathrm{~mW} \mathrm{~cm}^{-2} ; \mathrm{Co} \sim 20 \mu \mathrm{g} \mathrm{L}^{-1}$

Additionally, control experiments were performed using the sole action of the UV irradiance and that of the $\mathrm{H}_{2} \mathrm{O}_{2}$ content to verify that the positive results obtained in MC-LR cyanotoxin concentration reduction were ascribed to the role of the $\mathrm{HO}^{\circ}$ produced by the combined action of the factors governing the oxidation system. Dark experiments without irradiation or $\mathrm{H}_{2} \mathrm{O}_{2}$ were also conducted in order to evaluate the hydrolytic behavior of the target cyanotoxin.

As illustrated in Figure 5, an irradiance of $0.63 \mathrm{~mW}$ $\mathrm{cm}^{-2}$ achieved about $49 \%(48.96 \%)$ of the cyanotoxin removal for a treatment time of $60 \mathrm{~min}$, starting at 19.26 and finishing at $9.83 \mu \mathrm{g} \mathrm{L}^{-1} \mathrm{MC}-\mathrm{LR}$. Although a higher removal of MC-LR was obtained compared to the action of $\mathrm{H}_{2} \mathrm{O}_{2}$ alone, the elimination percentage was lower than that achieved through the coupled $\mathrm{UV} / \mathrm{H}_{2} \mathrm{O}_{2}$ system, as indicated previously. These results were consistent with the literature. It has been previously stated by several authors that direct MC photolysis results are low in comparison with those obtained when combining UV-C radiation with the action of an oxidizing agent such as $\mathrm{H}_{2} \mathrm{O}_{2}[8-10,12,14]$. It is important to consider the varying conditions under which the reported studies were performed, including the initial toxin concentration, oxidizing agent concentration, UV irradiance used and even the environmental conditions or the physicochemical properties of the water tested. For example, a high MC-LR concentration has been found to cause high optical density, leading to an interference in the UV radiation penetration. Consequently, a low UV light was absorbed by the $\mathrm{H}_{2} \mathrm{O}_{2}$ 


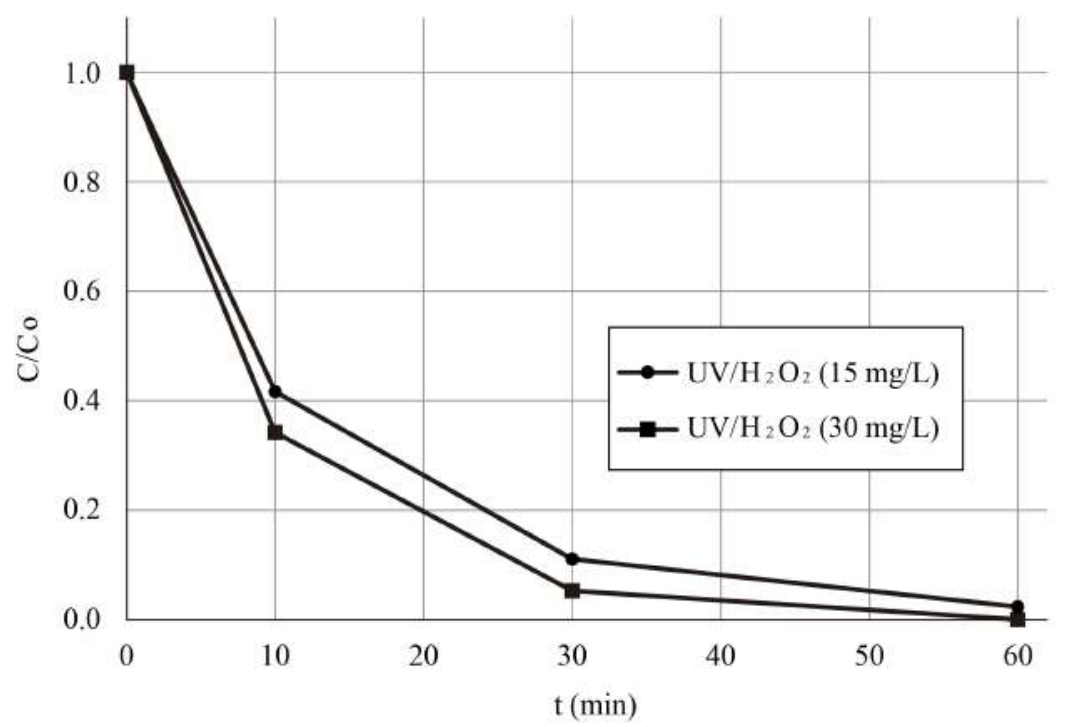

Figure 6 Removal profile of MC-LR cyanotixn vs time during the $\mathrm{UV} / \mathrm{H}_{2} \mathrm{O}_{2}$ system application in fresh natural water. $\left[\mathrm{H}_{2} \mathrm{O}_{2}\right]_{0}=15$ and $30 \mathrm{mg} \mathrm{L}^{-1}$; UV-C irradiance $=0.63 \mathrm{~mW} \mathrm{~cm}^{-2}$; Co $20 \mu \mathrm{g} \mathrm{L}^{-}$

molecules, decreasing the $\mathrm{HO}^{\circ}$ production. In addition, a high MC-LR concentration also can produce a wide range of reaction by-products which could compete with the MC-LR for the $\mathrm{HO}^{\circ}$ during the treatment [12]. For the conditions used in the current research, this phenomenon did not represent a problem.

With regard to the experiments using $\mathrm{H}_{2} \mathrm{O}_{2}$ without UV radiation (also shown in Figure 5), no significant MC-LR removal was achieved for a reaction time of $60 \mathrm{~min}$. The effect of $30 \mathrm{mg} \mathrm{L}^{-1} \mathrm{H}_{2} \mathrm{O}_{2}$ was also evaluated for a reaction time of $72 \mathrm{~h}$. Even after this extended treatment time, no effect above $13 \%$ was obtained. This phenomenon can be explained by the fact that $\mathrm{H}_{2} \mathrm{O}_{2}$ alone can take days to work, so no effective removal action can be achieved in short experimentation periods. This has been noted by other authors [15-18]. In fact, a $\mathrm{H}_{2} \mathrm{O}_{2}$ concentration of 60 $\mathrm{mg} \mathrm{L}^{-1}$ for $3.5 \mathrm{~h}$ under dark conditions was used and no damage was found to cyanobacteria cellular integrity [15]. Meanwhile, in the experiments performed in a shallow lake, cyanobacteria concentration dropped by $90 \%$ in $3 \mathrm{~d}$ and by $99 \%$ in $10 \mathrm{~d}$ with the application of $2 \mathrm{mg} \mathrm{L}^{-1} \mathrm{H}_{2} \mathrm{O}_{2}$ to all the lake [16]. Nevertheless, it is emphasized that it is difficult to compare laboratory with field results, given the variations among the water matrix quality and the hydraulic and environmental conditions in both scenarios, which affect the oxidizing reaction efficiency.

\subsection{Removal of MC-LR cyanotoxin in fresh natural water by the $\mathrm{UV} / \mathrm{H}_{2} \mathrm{O}_{2}$ system under optimal operating conditions}

As mentioned above, the intrinsic properties of the water to be used for evaluating the efficiency of a particular treatment is an issue of special concern, especially when scaling-up a laboratory process. In this regard, the oxidation capacity of the $\mathrm{UV} / \mathrm{H}_{2} \mathrm{O}_{2}$ system under optimal working conditions was also assessed using fresh natural water containing $20 \mu \mathrm{g} \mathrm{L}^{-1}$ of the target cyanotoxin. As shown in Figure 6 , and in comparison with the results illustrated in Figure 5 for the combined action of the UV irradiance and the $\mathrm{H}_{2} \mathrm{O}_{2}$ content, although positive results were obtained, the reduction of MC-LR in fresh water was slower for the first treatment stages, since $66.12 \%$ MC-LR removal was achieved using a $\mathrm{H}_{2} \mathrm{O}_{2}$ dose of 30 $\mathrm{mg} \mathrm{L}^{-1}$ for $10 \mathrm{~min}$ of treatment compared to the removal extent obtained in distilled water $(88.50 \%)$. This could be explained by the influence of natural constituents of fresh water including $\mathrm{Cl}^{-}, \mathrm{NO}_{3}{ }^{-}, \mathrm{PO}_{4}{ }^{3-} \cdot \mathrm{CO}_{3}{ }^{2-}$ and $\mathrm{SO}_{4}{ }^{2-}$ in the elimination of $M C-L R$, since the presence of these ions can limit the removal of $\mathrm{MC}$-LR. Indeed, $\mathrm{NO}_{3}$ - could also reduce the UV light intensity reaching the aqueous solution by acting as an internal filter, and the $\mathrm{CO}_{3}{ }^{2-}$ could eliminate $\mathrm{HO}^{\circ}[8,10-12]$. Furthermore, it has been established that the efficiency of the $\mathrm{UV} / \mathrm{H}_{2} \mathrm{O}_{2}$ system was affected not only by the organic matter levels and alkalinity, as mentioned in the majority of studies, but also by the presence of transition metals in natural water [19], including iron. This can be ascribed to the occurrence of other AOPs, such as the Fenton and photo-Fenton processes, which could increase the oxidation capacity of the treatment system. As shown in Table 2, low dissolved iron content was found in the natural water tested; therefore, the occurrence of the Fenton or photo-Fenton AOPs, was unlikely and, subsequently, the improvement of the MC-LR cyanotoxin removal capacity of the oxidation system with regard to that found in distilled water. 
Nonetheless, in spite of that, once the treatment time was extended $60 \mathrm{~min}$, similar reduction values were obtained for both water matrices $199.59 \%$ for the fresh water and $99.73 \%$ for the distilled water), as it can be observed by comparing Figure 5 and 6 . These promising results could be ascribed to the absorbance of the natural water at a 254 $\mathrm{nm}$ wavelength, which was fairly high compared to that of distilled water, as observed in Table 2; thus the probability of the UV light photons impacting $\mathrm{H}_{2} \mathrm{O}_{2}$ molecules was higher. This would result in $\mathrm{H}_{2} \mathrm{O}_{2}$ photolysis, instead of the UV light impact affecting only the organic matter and other constituents naturally present in the tested water, and, therefore, in the improvement of the $\mathrm{HO}^{\circ}$ production. Furthermore, according to the literature, $\mathrm{pH}$ of the water tested has been evidenced to have an influence on the oxidation capacity of the system. Indeed, it has been reported that neutral and slightly acid conditions were appropriate for MC-LR degradation. The acid conditions of the water matrices tested here could have favored the removal efficiency in the natural water samples with a $\mathrm{pH}$ of 5.8 and in the distilled water samples with a $\mathrm{pH}$ of 6.3 (Table 2) [12].

Natural water was also used to determine the efficiency of the oxidation process on removing MC-LR cyanotoxin at $0.63 \mathrm{~mW} \mathrm{~cm}^{-2}$ reducing the content of $\mathrm{H}_{2} \mathrm{O}_{2}$, as observed in Figure 6. Similar results were obtained by using 30 and $15 \mathrm{mg} \mathrm{L}^{-1}$ of $\mathrm{H}_{2} \mathrm{O}_{2}$; particularly, a removal of the target cyanotoxin of 99.59 and $98.08 \%$ were achieved, respectively, which were below the WHO recommended limit for MC-LR in drinking water. This indicates that the content of $\mathrm{H}_{2} \mathrm{O}_{2}$ for treating $20 \mu \mathrm{g} \mathrm{L}^{-1}$ of MC-LR cyanotoxin can be reduced by half, saving in operating costs. On the other hand, it is important to note that from the author's knowledge, $\mathrm{H}_{2} \mathrm{O}_{2}$ residual concentration after applying the treatment under similar working conditions is reduced by about half with respect to the initial content. This fact, added to the unstable character of $\mathrm{H}_{2} \mathrm{O}_{2}$, as described by Equation 9, leads to the necessity of using an additional disinfection agent to guarantee water disinfection when it is not consumed immediately.

$$
\mathrm{H}_{2} \mathrm{O}_{2} \rightarrow \mathrm{H}_{2} \mathrm{O}+\frac{1}{2} \mathrm{O}_{2}
$$

Therefore, by using the UV/ $\mathrm{H}_{2} \mathrm{O}_{2}$ system, high efficiencies in the removal of MC-LR cyanotoxin in fresh water under the operating conditions tested here were achieved. Nonetheless, further studies are suggested to be conducted in order to study the influence of the radiation intensity tested at different irradiance values since the $\mathrm{H}_{2} \mathrm{O}_{2}$ photolysis rate has been reported to be directly correlated with UV irradiance, and, therefore, in general terms, a high UV intensity improves the quantity of $\mathrm{HO}^{\circ}$ produced, while a low UV intensity limits photolysis [12]. However, it has been found that, even when a higher UV intensity contributes to a higher removal rate, it was not directly correlated to the toxin degradation rate [10]. Therefore, there is a point where the increase of UV intensity is not economically efficient as it will have a very small effect on the degradation rate.

Additionally, different constituents and physicochemical characteristics of the water matrix tested could influence the reaction, due to the trapping of $\mathrm{HO}^{\circ}$ and/or the reduction of the UV radiation penetration in the water [10-12], as indicated above. On the other hand, degradation by-products identification and relative quantification are recommended to be carried out since some of the reaction intermediates formed can be more toxic than the parent substances, even though it has been demonstrated that the by-products originated from MC-LR degradation with UV-C light were not toxic, because this reaction general occurs on the double conjugated bond from the aminoacidic fraction Adda ((2S,3S,4E,6E,8S,9S)-3-amino-9-methoxy-2,6,8-trimethyl10-phenyl-4,6-decadienoic acid) which is the responsible for the hepatotoxic effect of the toxin [20].

\section{Conclusions}

Preliminary studies in distilled water spiked with $20 \mu \mathrm{g}$ $L^{-1} M C-L R$ cyanotoxin showed that the combined action of the $\mathrm{H}_{2} \mathrm{O}_{2}$ dose and the UV radiation incidence significantly influenced the MC-LR removal after the AOP application. Under optimal operating conditions $10.63 \mathrm{~mW} \mathrm{~cm}^{-2} \mathrm{UV}$ irradiance and $30 \mathrm{mg} \mathrm{L}^{-1} \mathrm{H}_{2} \mathrm{O}_{2}$ content), a reduction of the MC-LR initial content of $99.73 \%$ was observed, being the oxidation capacity of the system faster during the first initial stage of the process application, since around $88.50 \%$ MC-LR removal was achieved in only $10 \mathrm{~min}$ of treatment. Additionally, UV irradiance alone was shown to be more effective than the degradation found with the sole action of $\mathrm{H}_{2} \mathrm{O}_{2}$, as at 60 min of treatment removal percentages were still not significant.

When evaluating the oxidation potential of the $U V / \mathrm{H}_{2} \mathrm{O}_{2}$ system in natural fresh water, an effective MC-LR removal was also observed using the combined action of UV irradiance and the oxidizing reagent $\mathrm{H}_{2} \mathrm{O}_{2}$, reaching a removal percentage of $99.59 \%$, which was well below the recommended limit of $1 \mu \mathrm{g} \mathrm{L}^{-1}$ established by the WHO for $\mathrm{MC}-\mathrm{LR}$ in drinking water. $\mathrm{A} \mathrm{H}_{2} \mathrm{O}_{2}$ content of $15 \mathrm{mg} \mathrm{L}^{-1}$ was also tested and, although $98.08 \%$ of MC-LR elimination was found for a reaction time of $60 \mathrm{~min}$, the WHO advisable limit was not surpassed.

In this way, the application of the $\mathrm{UV} / \mathrm{H}_{2} \mathrm{O}_{2}$ system could be considered as an alternative treatment to be used for producing drinking water, providing the accomplishment of the whole set of water quality standards included in the legislation. 


\section{Acknowledgments}

To the GDCON research group and to the Vice-Rectory of Research of the University of Antioquia for the financial support.

\section{References}

[1] J. O'Neil, T. Davis, M. Burford, and C. Gobler, "The rise of harmful cyanobacteria blooms: The potential roles of eutrophication and climate change," Harmful Algae, vol. 14, February 2012. [Online]. Available: https://doi.org/10.1016/j.hal.2011.10.027

[2] I. Chorus and J. Bartram. (1999) Toxic cyanobacteria in water: A guide to their public health consequences, monitoring and management. [E \& FN Spon]. [Online]. Available: https://bit.ly/ $2 \times 9 \mathrm{GiZH}$

[3] H. Hudnell, "Cyanobacterial poisoning in livestock, wild mammals and birds - an overview," in Cyanobacterial Harmful Algal Blooms: State of the Science and Research Needs, I. Stewart, A. Seawright, and G. Shaw, Eds. New York: Springer, 2008, pp. 950-955.

[4] S. Merel, M. Villarín, K. Chung, and S. Snyder, "Spatial and thematic distribution of research on cyanotoxins," Toxicon, vol. 76, December 15 2013. [Online]. Available: https://doi.org/10.1016/j.toxicon.2013. 09.008

[5] S. Merel and et al, "State of knowledge and concerns on cyanobacterial blooms and cyanotoxins," Environment International, vol. 59, September 2013. [Online]. Available: https://doi.org/10. 1016/j.envint.2013.06.013

[6] S. Merel, M. Clément, and O. Thomas, "State of the art on cyanotoxins in water and their behaviour towards chlorine," Toxicon, vol. 55, no. 4, April 1 2003. [Online]. Available: https: //doi.org/10.1016/j.toxicon.2009.10.028

[7] B. Hitzfeld, S. Höger, and D. Dietrich, "Cyanobacterial toxins: removal during drinking water treatment, and human risk assessment," Environ Health Perspect., vol. 108, no. 1, March 2000. [Online]. Available: https://doi.org/10.1289/ehp.00108s1113

[8] X. He and et al, "Efficient removal of microcystin-lr by uv-c/h2o2 in synthetic and natural water samples," Water Research, vol. 46, no. 5, April 1 2012. [Online]. Available: https://doi.org/10.1016/j. watres.2011.11.009

[9] X. He and et al, "Destruction of microcystins (cyanotoxins) by UV-254 nm-based direct photolysis and advanced oxidation processes (AOPs): Influence of variable amino acids on the degradation kinetics and reaction mechanisms," Water Research, vol. 74, May 1 2015. [Online]. Available: https://doi.org/10.1016/j. watres.2015.02.011
[10] R. Qiao, N. Li, X. Qi, Q. Wang, and Y. Zhuang, “Degradation of microcystin- $r$ by uv radiation in the presence of hydrogen peroxide," Toxicon, vol. 45, no. 6, pp. 745-52, May 2005.

[11] R. Qiao and et al, "Degradation of microcystin-RR by combination of UV/H2O 2 technique," Chinese Chem. Lett., vol. 16, pp. 1271-1274, Sep. 2005.

[12] L. Li and et al, "Experimental and model comparisons of $\mathrm{H} 2 \mathrm{O} 2$ assisted UV photodegradation of Microcystin-LR in simulated drinking water," Journal of Zhejiang University-SCIENCE A, vol. 10 , no. 11, November 2009. [Online]. Available: https://doi.org/10.1631/ jzus.A0820642

[13] W. Song, V. Ravindran, and M. Pirbazari, “Process optimization using a kinetic model for the ultraviolet radiation-hydrogen peroxide decomposition of natural and synthetic organic compounds in groundwater," Chemical Engineering Science, vol. 63, no. 12, Jun 2008. [Online]. Available: https://doi.org/10.1016/j.ces.2008.03.024

[14] B. Wang and et al, "The combined effects of uv-c radiation and h2o2 on microcystis aeruginosa, a bloom-forming cyanobacterium," Chemosphere., vol. 141, Dec 2015. [Online]. Available: https: //doi.org/10.1016/j.chemosphere.2015.06.020

[15] X. Huo, D. Chang, J. Tseng, M. Burch, and T. Lin, "Exposure of microcystis aeruginosa to hydrogen peroxide under light: Kinetic modeling of cell rupture and simultaneous microcystin degradation," Environ Sci Technol., vol. 49, no. 9, May 52015. [Online]. Available: https://doi.org/10.1021/acs.est.5b00170

[16] H. Matthijs and et al, "Selective suppression of harmful cyanobacteria in an entire lake with hydrogen peroxide," Water Res., vol. 46, no. 5, Apr 1 2012. [Online]. Available: https://doi.org/10.1016/j.watres.2011.11.016

[17] D. Barrington and A. Ghadouani, "Application of hydrogen peroxide for the removal of toxic cyanobacteria and other phytoplankton from wastewater," Water Res., vol. 42, no. 23, Nov 5 2008. [Online]. Available: https://doi.org/10.1021/es801717y

[18] D. Barrington, E. Reichwaldt, and A. Ghadouani, "The use of hydrogen peroxide to remove cyanobacteria and microcystins from waste stabilization ponds and hypereutrophic systems," Ecological Engineering, vol. 50, Jan 2013. [Online]. Available: https://doi.org/10.1016/j.ecoleng.2012.04.024

[19] X. He, A. de la Cruz, and D. Dionysiou, "Destruction of cyanobacterial toxin cylindrospermopsin by hydroxyl radicals and sulfate radicals using UV-254 $\mathrm{nm}$ activation of hydrogen peroxide, persulfate and peroxymonosulfate," Journal of Photochemistry and Photobiology A: Chemistry, vol. 251, Jan 1 2013. [Online]. Available: https: //doi.org/10.1016/j.jphotochem.2012.09.017

[20] K. Tsuji and et al, "Stability of microcystins from cyanobacteria: effect of light on decomposition and isomerization," Toxicon, vol. 33, no. 12, Dec 1995. [Online]. Available: https://doi.org/10.1016/ 0041-0101(95)00101-8 